\title{
CITIZENSHIP AND COMMUNITY LIFE WITH REFERENCE TO THE CONCEPT OF DEMOCRACY AMONG STUDENTS WITH INTELLECTUAL DISABILITY: AN EXPERIMENTAL STUDY
}

\author{
Sr. Asheena Rose ${ }^{1}$, Dr. Saumya Chandra $2 \square$ \\ ${ }^{1}$ Assistant Professor, Department of Special Education, Ramakrishna Mission Vivekananda Educational \& \\ Research Institute, Coimbatore, Tamil Nadu, India. \\ ${ }^{2}$ Faculty of Disability Management and Special Education, Coimbatore, Tamil Nadu, India.
}

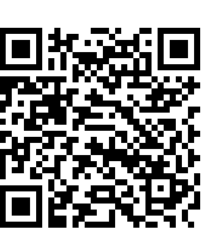

\section{ABSTRACT}

Being a citizen of a country is the status of citizenship. If one has citizenship of a country, he would have the right to live there, work, vote, use community resources, pay taxes etc. Citizenship for persons with Intellectual Disability (PwID) is exactly the same as citizenship for anyone else. Citizenship is important for all of us. Having an ID is not a barrier to citizenship in fact it is useful because it helps communities come together, but it does become a barrier if society lets prejudice and power get in the way. The fundamental rights in our constitution are considered as basic human rights of all citizens, irrespective of their gender, caste, religion, disability etc. whereas when it comes to PwID, it sounds so difficult. Therefore, for this study 10 Adolescent students with Mild

Received 16 September 2021

Accepted 16 October2021

Published 31 October2021

\section{CorrespondingAuthor}

Dr. Saumya Chandra,

saumyachandra72@gmail.com

DOI

10.29121/granthaalayah.v9.i10.2021 .4349

Funding: This research received no specific grant from any funding agency in the public, commercial, or not-for-profit sectors.

Copyright: (C) 2021 The Author(s). This is an open access article distributed under the terms of the Creative Commons Attribution License, which permits unrestricted use, distribution, and reproduction in any medium, provided the original author and source are credited.

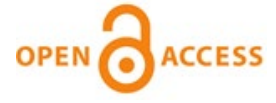
and moderate Intellectual disability were selected through purposive sampling method and a training program was organized to find out the understanding of these intangible concepts. Five selected topics i.e., community participation, community resources, fundamental rights, self-advocacy, election were included in the training program. The data collected was analyzed using both qualitative and quantitative methods both. The finding of the study reveals that through proper planning, role play, exposure in community and using visual clues, the awareness level of democracy, citizenship and election etc. can definitely enhance the understanding of citizenship among PwID.

Keywords: Citizenship, Fundamental Rights, Democracy, Students with Intellectual Disability

\section{INTRODUCTION}

In ancient India disability was never considered as a separate entity and it was accepted as any other different feature. History says that, Indians with disabilities have proved that disability as just a state of mind. Amazing people who have not let their disability hold them back them in any way. From performing in international arenas to bagging gold medals in sports events, there is nothing these champions cannot do! They have made us so proud. Indians who have proved this statement right by excelling in various fields in spite of their disability and who inspire us in so many ways every day.

India has a growing disability rights movement and one of the more progressive policy frameworks in the developing world. But a lot more needs to be done in implementation and "getting the basics right". Preventive health programs need to be deepened and all children screened at a young age. PwID need to be better integrated into society by overcoming stigma, need to be empowered with employable skills; and the private sector needs to be 
encouraged to employ them. The scale of disability in India needs to be better understood by improving the measurement of disability. Most importantly PwID should themselves be made active participants in the development process.

\section{INTELLECTUAL DISABILITY}

PwID have been identified as having limited social support structures. Therefore, interventions are to be focused on promoting their social presence and integration. Social support and community participation has been identified as a major contributor to quality of life. However, previous studies have shown that this does not always lead to the formation of social relationships. PwID have restricted social networks despite being involved in more activities.

\section{(The pdf downloaded on 5th August 2021)}

\section{Community life:}

Research studies advocate that PwID should be supported to participate fully in the community. But what does "community participation" mean? What is "the community" Bray and Gates (2003)? A community is a familiar thread used to bring people together to advocate and support each other in the fight to overcome those threats. As human beings, we need a sense of belonging, and that sense of belonging is what connects us to the many relationships we develop. Communities are also rich in a resource that is where their collective aspect comes into play. So, for a positive experience of community participation PwID need to be able to be involved in various community places and activities, free from discrimination and abuse from other community members (Menard 1997).

\section{Community participation and PwID}

The three important points are that "the community" involves

- A place where other people do things

- Other people to do things with and get to know

- A feeling of belongingness

Community participation can be experienced as good or bad. Some of the things that make it more enjoyable are:

- knowing the places and people; knowing how to find their way around

- choosing whether they want to be involved

- knowing they will have support when they need it

- not being made to go to places where the person has had a bad experience in the past

- knowing that the people there accept the person and like

- being involved in social activities with other people

- knowing what to do in that place or activity

\section{Democracy}

The word "democracy" means "rule by the people." Democracy requires that each individual without any discrimination be free to participate in the community's self-government. Thus, political freedom lies at the heart of the concept of democracy. Let's talk about India. India is the world's largest democracy and here 
democracy gives its citizens the right to vote irrespective of their caste, color, creed, religion, and gender. And, this democracy provides us with some rights

- Right to Equality

- Right to Freedom

- Right against Exploitation

- Right to Freedom of Religion

- Cultural and Educational Rights

- Right to Constitutional Remedies

\section{Real}

Persons with Disabilities - Governance and Democracy to Make the Right

Rights of Persons with Disabilities is equal to human rights and human dignity of PwD and it is unchallengeable and inseparable datum. Voices of PwD requires to be taken to main stream societies for which appropriate laws and policies are inevitable therefore every political party, organizations for social justice. Now, in line with the concept of community and democracy, we will see what is citizenship as, then only the triad of the three entities: community, democracy and citizenship can be made possible.

\section{Citizenship}

Citizenship comes from the Latin word for city, because in the earlier days of human governments, people identified themselves as belonging to cities more than countries. In order to become a citizen, one must have the following:

- The membership of the state

- The social and political rights

- Sentiment of devotion to the state

\section{Review of the related literature}

Byhlin and Käcker (2018) conducted a study on “I Want to Participate!' Young Adults with Mild to Moderate Intellectual Disabilities: How to Increase Participation and Improve Attitudes". The participants stated that they wished to be listened to as adults, and to participate in decisions about daily activity/sheltered employment. They wanted to participate, and the opportunity to do so would require an accepting environment.

Friedman (2018) conducted a study on "Every Vote Matters:" This study explored the experiences of people with intellectual and developmental disabilities voting in the 2016 United States general election. Although the majority of participants voted, they still faced a number of barriers which point to larger problems with the United States election process, and discrimination against people with disabilities.

Capri et al. (2018) conducted a study on "Intellectual disability rights and inclusive citizenship in South Africa: What can a scoping review tell us?" PwID face compound difficulties when trying to assert their constitutionally entitled rights.

Clifford (2018) conducted a study on "Democratic Care and Intellectual Disability: More than Maintenance". This study explains care by three activities: maintaining, continuing, and repairing. These activities give care a maintenance 
quality, which is problematic given that caring often takes place within contexts of inequality and domination.

McCausland et al. (2018) conducted a study on "The exercise of human rights and citizenship by older adults with an intellectual disability in Ireland". This review explains the UN Convention on the Rights of Persons with Disabilities (CRPD) provides the benchmark for assessing human rights and citizenship for people with disabilities.

Wiley (2017) conducted a study on "Community Involvement of Young Adults with Intellectual Disabilities: Their Experiences and Perspectives on Inclusion". They found out that the community involvement of PwID varies depending on the opportunities and supports available to them.

\section{Rationale of the study}

PwID attending Vocational group education in special schools need to know about democracy. PwID should enjoy all the rights and privileges which were not accessible for them in the past and they should know they are the citizens of the country and they also can vote, participate in community activities, and enjoy all the fundamental rights etc.

\section{Objectives of the study}

1) To find out the level of awareness among PwID about the concept of democracy

2) To make the PwID aware of the meaning of democracy

3) To make the PwID aware of the meaning of citizenship

4) To advocate about the rights and duties of democracy among PwID

5) To find out their understanding of democracy and citizenship after intervention

\section{Hypothesis}

1) There will be no significant difference in about the concept of democracy in pre and post test results among PwID.

2) There will be no significant difference in about the concept of citizenship in pre and post-test results among PwID.

\section{Research questions}

1) What is the effect of citizenship training program on students understanding of the concept of democracy?

2) What is the effect of citizenship training program on students' understanding of the concept of citizenship?

\section{Research Design}

Here in this study the researchers selected experimental design that is single group pre and post-test design under informal experimental design. Purposive sampling has been employed for the selection of the samples for the present study. 


\section{Inclusion criteria for sample selection}

- No. of students: 10

- Age group: 18 years and above

- Vocational group

- Gender: Male and Female

- Level: Mild and Moderate Intellectual Disability

\section{Detail of the tool and intervention}

The researcher used the following:

- Development of pre and post-test assessment rating scale for the understanding of citizenship and democracy

- Teaching citizenship and democracy using hands on experience activity-based lesson plan

\section{Formation of the tool items}

The researcher used hands on experience for teaching citizenship and democracy under the selected five subthemes: community participation, community resources, self- advocacy, fundamental rights and election.

\section{Validity and reliability of the research tool}

To establish the validity, the researcher adopted face validity. The experts' opinions were taken into consideration and based on those necessary corrections were done to maintain the validity of the respective tool.

Split-half method was used to establish the reliability of the tool. Split- half method is most common method of estimating the internal consistency reliability. The correlation co-efficient value found to be 0.72 and it is highly significant at 0.01 levels. Based on all the standardization process, necessary corrections were made in the final preparation of the tool.

\section{Tool}

Pre and post-test performance of the student was recorded on 3 points rating scale for understanding the concept of citizenship and democracy.

\section{Data analysis}

$R Q$ 1: What is the effect of citizenship training program on students' understanding of the concept of democracy?

Pre-test was conducted for the students $(n=10)$ on their knowledge about the concept of democracy. An intervention in the form of activities was given to the students thereafter. A post-test was then conducted to find the change in knowledge levels after intervention. Table 1 presents the means of pre-test and post-test scores on knowledge level about democracy for the students who participated in the study. 
Table 1 Comparison of Pre and Post-test Mean score of understanding the level of the students about the concept of democracy

$\begin{array}{ccc}\text { Sample } & \text { Test } & \text { Mean score } \\ 10 & \text { Pre test } & 62 \\ & \text { Post test } & 170\end{array}$

Since the sample size is small $(\mathrm{n}=10)$ and it is difficult to ascertain whether the distribution of scores follows a normal distribution in this dataset, it was decided to use the Wilcoxon-sign rank test to find the answer to the research question 1 . These values found out from the test are presented in the Table 2.

\begin{tabular}{ccccccc}
\hline \multicolumn{5}{c}{ Table $\mathbf{2}$ Wilcoxon signed rank test for testing improvement in knowledge of democracy } \\
\hline Sample & Gender & Pre-test score & Post-test score & Diff. score & Rank & Signed ranks \\
\hline S1 & M & 8 & 23 & 15 & 10 & 10 \\
\hline S2 & M & 6 & 20 & 14 & 9 & 9 \\
S3 & M & 5 & 15 & 10 & 5 & 5 \\
\hline S4 & M & 6 & 19 & 13 & 7.5 & 7.5 \\
\hline S5 & M & 5 & 13 & 8 & 2 & 2 \\
S6 & F & 8 & 21 & 13 & 7.5 & 7.5 \\
S7 & F & 6 & 17 & 11 & 6 & 6 \\
\hline S8 & F & 7 & 16 & 9 & 3.5 & 3.5 \\
S9 & F & 6 & 15 & 9 & 3.5 & 3.5 \\
\hline S10 & F & 5 & 11 & 6 & 1 & 1 \\
\hline
\end{tabular}

The test statistic of the Wilcoxon-signed rank test, ' $w$ ' was calculated and found to be 55. Comparing it with the critical value for ' $w$ ' obtained from the critical ' $w$ ' statistical table, it can be seen that for $n=10, \alpha=0.05$, and two-tailed test, the critical value of $\mathrm{w}$ is 8 . This is shown in Table 3 mentioned below.

\begin{tabular}{|ccc|}
\hline \multicolumn{2}{|c|}{ Table 3 Comparison of calculated and critical values of test statistic ' $\mathbf{w}$ ' } \\
\hline $\begin{array}{c}\text { Sample design } \\
\text { (n) }\end{array}$ & $\begin{array}{c}\text { Test statistic calculated } \\
\text { value(W) }\end{array}$ & $\boldsymbol{\alpha}=\mathbf{0 . 0 5}$, Critical value $(\mathbf{W})$ from $\mathbf{~ W ~}$ \\
10 & 0 & table
\end{tabular}

Comparing calculated $\mathrm{W}$ and critical $\mathrm{W}$, it is seen that calculated $\mathrm{W}(=0)<$ critical W $(=8)$. Since calculated W $(=0)<$ critical W $(=8)$, Ho is rejected.

Since Ho is rejected, the increase in post test scores from pretest score is statistically significant. This means that the observed differences, which are improvements, are due to the effects of the intervention indicating that the intervention investigated in this study is effective in improving the targeted dependent variables. 
RQ 2: What is the effect of citizenship training program on students' understanding of the concept of citizenship?

Pre-test was conducted for the students $(n=10)$ on their knowledge about the concept of citizenship. An intervention in the form of activities was given to the students thereafter. A post-test was then conducted to find the change in knowledge levels after intervention.

Table 4 Comparison of pre and post test result about the concept of citizenship among SwID

\begin{tabular}{cccc}
\hline Sample Design N & Test & Mean & SD \\
10 & Pre- Test & 6.2 & 1.0770 \\
& Post-Test & 17 & 3.5496
\end{tabular}

This table represents the mean scores, pre and post test scores and standard deviation about the concept of citizenship when assessed by the students. Significant difference exists the comparison of pre and post test results about the concept of citizenship. From pre-test to post-test mean and standard deviation increased. So, it is effective training program about citizenship for the students. The Wilcoxon-signed rank test is done by finding the difference between post-test and pre-test scores, ranking them and giving the ranks signs. These values are presented in table.

\begin{tabular}{|c|c|c|c|c|c|c|c|}
\hline Sample & Gender & $\begin{array}{l}\text { Level of } \\
\text { disability }\end{array}$ & Pre-test & Post-test & Diff score & rank & $\begin{array}{c}\text { signed } \\
\text { ranks }\end{array}$ \\
\hline 1 & Male & 65 & 8 & 23 & 15 & 10 & 10 \\
\hline 2 & Male & 61 & 6 & 20 & 14 & 9 & 9 \\
\hline 3 & Male & 48 & 5 & 15 & 10 & 5 & 5 \\
\hline 4 & Male & 54 & 6 & 19 & 13 & 7.5 & 7.5 \\
\hline 5 & Male & 46 & 5 & 13 & 8 & 2 & 2 \\
\hline 6 & Female & 61 & 8 & 21 & 13 & 7.5 & 7.5 \\
\hline 7 & Female & 55 & 6 & 17 & 11 & 6 & 6 \\
\hline 8 & Female & 60 & 7 & 16 & 9 & 3.5 & 3.5 \\
\hline 9 & Female & 58 & 6 & 15 & 9 & 3.5 & 3.5 \\
\hline 10 & Female & 45 & 5 & 11 & 6 & 1 & 1 \\
\hline
\end{tabular}

The test statistic of the Wilcoxon-signed rank test, ' $w$ ' was calculated and found to be 55. Comparing it with the critical value for ' $w$ ' obtained from the critical ' $w$ ' statistical table, it can be seen that for $n=10, \alpha=0.05$, and two-tailed test, the critical value of $\mathrm{w}$ is 8 . This is shown in Table 6 below. 
Table 6 Comparison of calculated and critical values of test statistic ' $w$ '

$\begin{array}{ccc}\begin{array}{c}\text { Sample design } \\ \text { (n) }\end{array} & \begin{array}{c}\text { Test statistic calculated value } \\ \text { (W) }\end{array} & \begin{array}{c}\boldsymbol{\alpha}=\mathbf{0 . 0 5} \text {, Critical value (W) from } \mathbf{W} \\ \text { table }\end{array} \\ 10 & 0 & 8\end{array}$

Comparing calculated $\mathrm{W}$ and critical $\mathrm{W}$, it is seen that calculated $\mathrm{W}(=0)<$ critical W (=8). Since calculated W $(=0)<$ critical W $(=8)$, Ho is rejected.

Since Ho is rejected, the increase in post test scores from pretest score is statistically significant. This means that the observed differences, which are improvements, are due to the effects of the intervention indicating that the intervention investigated in this study is effective in improving the targeted dependent variables.

Following are the results based on the objectives selected for the study

objective 1: To find out the level of awareness about the concept of democracy among Students with Intellectual Disability

The study was conducted in a special school located in deep south India. A rating scale was developed by the researcher to assess the awareness about the concept of democracy among SwID in qualitative and quantitative way. The researcher assessed the samples with the rating scale before the intervention. The researcher collected the data using qualitative and quantitative method.

\section{Objectives 2 and 3: To make the SwID aware of the meaning of democracy and citizenship}

Before executing the intervention plan proper permission was taken from the administrative body of the above said special school for data collection. After getting permission, having received consent from the parents, based on the assessment, intervention was given to SwID. The concept of democracy and citizenship includes subjects such as community participation, community resources, self- advocacy, fundamental rights and election. During the intervention, various activities (role play, drama, skit etc.) were given to the sample and feedback was collected through questionnaire. SwID

Objective 4: To advocate about the rights and duties of democracy among

To enable the students to understand about rights and duties of democracy, the researcher used related activities, skit, drama, role play etc. The understanding and knowledge of SwID about rights and duties of democracy before and after the intervention program was evaluated by the researcher

\section{Objective 5: To evaluate the understanding about citizenship and democracy among SwID before and after intervention}

The pre-test mean score of SwID understanding about the concept of citizenship and democracy is 6.2 whereas the post-test means score of the same group is 17. Wilcoxon sign rank test shows that there is a significant difference between pre-test and post test score of SwID in understanding the concept of democracy and citizenship. The above-mentioned table 4 shows that it is significant at the level of 0.05 
Following are the results based on the Hypothesis selected for the study:

Hypothesis 1: There will be no significant difference in about the concept of democracy in pre and post test results among SwID

The pre-test mean score of SwID about understanding about the concept of democracy is 6.2 whereas the post-test means score of the same group is 17 . Wilcoxon sign rank test shows that there is a significant difference between pre and post test scores of SwID in understanding the concept of democracy as calculated W $(=0)<$ critical W $(=8)$. This means that the observed differences, which are improvements, are due to the effects of the intervention indicating that the intervention investigated in this study is effective in improving the targeted dependent variables. Hence the first hypothesis is rejected.

Hypothesis 2: There will be no significant difference in about the concept of citizenship in pre and post-test results among SwID

The pre-test mean score and standard deviation of SwID in understanding about the concept of democracy is 6.2 and 1.0770, whereas the post-test means score and standard deviation of the same group is 17 and 3.5496. Wilcoxon sign rank test shows that there is a significant difference between pre and post test scores of SwID. Hence second hypothesis is also rejected.

\section{Educational implication of the study}

The study gives an overview about the awareness level of SwID about citizenship and democracy. The present study consists of a training package to develop and improve the awareness about rights and duties of citizens for SwID. Also, it guides special educators to create awareness about rights and duties of the citizens through selected activities meant for them. Special educators too are benefited as they can teach advocacy to SwID about their rights.

\section{Scope of further research}

In order to overcome the limitations of the present study and in views of the findings that have come out, and on the basis of personal experiences gained by the researchers, a few suggestions could be stated such as there is a wide scope to conduct experimental study with control group and to select more than one school for data collection. The results of the study clearly indicate that awareness about rights and duties of citizens can be included as a part of IEP for SwID at prevocational level.

\section{REFERENCES}

Bada Math,S., Gowda, G. \& Gowd, M. (2019).The Rights of Persons with Disability Act, 2016: Challenges and opportunities, Indian journal of psychiatry, 61 (4). Retrieved from https://www.ncbi.nlm.nih.gov/pmc/articles/PMC6482682/

Bray, A. \& Gates, S. (2003). Community participation for Adult with an Intellectual Disability, $\quad$ Retrieved from http://www.disright.org/sites/default/files/nhc_communitypart.pdf

Byhlin, S. \& Käcker, P. (2018). 'I Want to Participate!' Young Adults with Mild to Moderate Intellectual Disabilities: How to Increase Participation and Improve Attitudes. Scandinavian Journal of Disability Research, 20(1), pp.172-181. Retrieved from https://doi.org/10.16993/sjdr.58 
Capri,C., Abrahams, L., Mckenzie, J.\& Coetzee, O. (2018). Intellectual disability rights and inclusive citizenship in South Africa: What can a scoping review tell us? .African Journal of Disability. Retrieved from https://doi.org/10.4102/ajod.v7i0.396

Clark, R.J. (2005), research models and methodologies, Retrieved from https://documents.uow.edu.au/content/groups/public/@web/@commer ce/documents/doc/uow012042.pdf

Clifford Simplican, S. (2018). Democratic Care and Intellectual Disability: More than Maintenance, Journal of Ethics and Social Welfare,12(4), pp.298-313. Retrieved from https://doi.org/10.1080/17496535.2018.1452954

Conley Wright, A. \& Taylor, S. (2014). Advocacy by parents of young children with special needs: Activities, processes, and perceived effectiveness. Journal of Social Service Research, 40 (5), 591-605. Retrieved from https://doi.org/10.1080/01488376.2014.896850

Femec, L., Kis-Glavas,L,\& Masic, V. (2017). Voting Opportunities for Persons with Disabilities.Original scientific paper.

Friedman, C. (2018). Every Vote Matters: Experiences of People with Intellectual and Developmental Disabilities in the 2016 United States General Election. Review of Disability Studies: An International Journal, 14 (1). Retrieved from https://www.rdsjournal.org/index.php/journal/article/view/765

Hilberink, S. \& Cardol, M. (2018). Citizenship according to the UNCRPD and in practice : a plea for a broader view. Journal of Disability and Society, 34(2), pp. 326-331. Retrieved from https://doi.org/10.1080/09687599.2018.1556490

Kenpro, (2012). Designs and Methodology, Kenya projects organization, Retrieved from http://www.kenpro.org/research-design-and-methodology/

Kopel, C. (2017). Suffrage for People with Intellectual Disabilities and Mental Illness: Observations on a Civic Controversy. Yale Journal of Health Policy, Law, and Ethics, 17(1). Retrieved from https://heinonline.org/HOL/LandingPage?handle=hein.journals/yjhple17 \&div=8\&id=\&page $=$

Lord,J., Ashley Stein, M.\& Fiala-Butor, J.(2014).Facilitating an Equal Right to Vote for Persons with Disabilities. Journal of Human Rights Practice, 6(1), pp. 115139. Retrieved from https://doi.org/10.1093/jhuman/hut034

Lucio, J. \& Anson, J. (2015). Children as members of a community: Citizenship, participation and educational development - an introduction to the special issue. European Educational Research Journal, 14 (2). Retrieved from https://doi.org/10.1177/1474904115571794

Mallander , O., Mineur , T., Henderson, D., Tideman, M.,( 2018). Self-Advocacy for People with Intellectual Disability In Sweden - organizational similarities and differences. Journal of Disability studies Quarterly, 38(1). Retrieved from https://doi.org/10.18061/dsq.v38i1.5505

Michelle Aldersey, H. \& Jackson Haines, S. (2018). Teaching and Supporting Students with Intellectual Disabilities in Democratic Republic of Congo. Journal of International Special Needs Education, 21(1), pp. 21-31. Retrieved from https://doi.org/10.9782/2159-4341-20.2.90

Milner, P. \& Kelly, B. (2007). Community participation and inclusion : people with disabilities defining their place. Journal of Disability \& Society. 24(1), pp. 4762. Retrieved from https://doi.org/10.1080/09687590802535410 
Mittler, P. (2015). The UN Convention on the Rights of Persons with Disabilities: Implementing a Paradigm Shift. Journal of policy and practice in intellectual disabilities, Original Article 12 (2), 79-89. Retrieved from https://doi.org/10.1111/jppi.12118

Panwar, P. (2016).11 Extraordinary Personalities with Disabilities, revised at 12:16 on 28/1/2016 Retrieved from https://www.oneindia.com/feature/in-pics10-extraordinary-personalities-with-disabilities-1580686.html

Praveen, Rights of Disabled Persons, Retrieved from http://www.legalserviceindia.com/legal/article-98-rights-of-disabledpersons.html

Reenen, T. \& Combrin, H. (2011). The UN CONVENTION on the Rights Of Persons with Disabilities In Africa, International Journal of Human Rights, Sur File on The Rights of Persons with Disabilities. Retrieved from https://heinonline.org/HOL/LandingPage?handle=hein.journals/surij14\& div $=11 \& i d=\&$ page $=$

Shree, A. \& Shukla, P.C. (2016). Intellectual Disability: definition, classification, causes and characteristics, Learning Community, 7 (1), 9-20. Retrieved from https://doi.org/10.5958/2231-458X.2016.00002.6

Sigan, L.H. \& William, E. M. (2008). Coping Strategies of Adults with Mild Intellectual Disability for Stressful Social Interactions. Journal of Mental Health Research in Intellectual Disabilities. 1 (2), 109- 127. Retrieved from https://doi.org/10.1080/19315860801988426

Singh, H. (2019). Citizenship of India: Constitutional Provision, Indian Polity, revised at 12.06 on 30/04/2019 Retrieved from https://www.jagranjosh.com/general-knowledge/citizenship1434782934-1

Sinha, R. (2019). The Citizenship (Amendment) Bill, 2019. PRS Legislative Research,, Retrieved from https://www.prsindia.org/theprsblog/explainercitizenship-amendment-bill-2019

Skaratad, K. (2018). Ensuring human rights for Persons with Intellectual Disabilities? Self-determination policies and the use of force in the case of Norway, The International Journal of Human Rights, 22(6), 774-800. Retrieved from https://doi.org/10.1080/13642987.2018.1454903

Stainton, T. \& Clare, I. (2012) Human rights and intellectual disabilities: an emergent theoretical paradigm?,Journal of Intellectual Disability Research, 56(11), pp 1011-1013. Retrieved from https://doi.org/10.1111/jir.12001

Tideman, M. \& Syensson, 0. (2015). Young people with intellectual disability- the role of self-advocacy in a transformed Swedish welfare system. International journal of Qualitative studies in health and well -being. Retrieved from https://doi.org/10.3402/qhw.v10.25100

Verdonschot, M., Dewitt,L., Reichrath, E.,\& Buntinx, Wil.(2009). Community participation of people with an intellectual disability: A review of empirical findings. Journal of Intellectual Disability Research 53(4):303-318. Retrieved from https://doi.org/10.1111/j.1365-2788.2008.01144.x

Verdonschot, M., De Witte, L., Reichrath, E. \& Buntinx, W. (2009). Community participation of people with an intellectual disability : A review of empirical findings. Journal of Intellectual Disability Research 53(4), 303- 318. Retrieved from https://doi.org/10.1111/j.1365-2788.2008.01144.x 
Wiley,J. (2017). Community Involvement of Young Adults with Intellectual Disabilities: Their Experiences and Perspectives on Inclusion. Journal of Applied Research Intellectual Disability, 30(5), 859-871. Retrieved from https://doi.org/10.1111/jar.12276

http://citeseerx.ist.psu.edu/viewdoc/download?doi=10.1.1.498.9056\&rep=rep1\& type $=$ pdf 